\title{
PENGARUH PENDAPATAN SEKTOR PARIWISATA TERHADAP KESEJAHTERAAN MASYARAKAT DAN PERTUMBUHAN EKONOMI LAMPUNG TIMUR
}

\author{
${ }^{1}$ Susi Sulastri, ${ }^{2}$ Eka Pariyanti, \\ STIE Lampung Timur \\ Email: ekaparianti10@gmail.com
}

\section{FIDUSIA}

Jurnal Ilmiah Keuangan dan Perbankan

ISSN Cetak : 2621-2439

ISSN Online : 2621-2447

Kata Kunci : Pendapatan Sektor Pariwisata, Kesejahteraan Masyarakat ,Pertumbuhan Ekonomi

\section{ABSTRAK}

Lampung Timur kini terus berupaya membangkitkan pariwisata sebagai salah satu sektor unggulan. Beberapa obyek wisata yang terdapat di Kabupaten Lampung Timur, antara lain Dam Swadaya, Dam Negara Natin, Balai Benih Induk Holtikultura, Taman Nasional Way Kambas (TNWK), Pesanggrahan Way Curup, Taman Purbakala Pugung Raharjo, Pantai Kerang Mas, Desa Tradisional Wana, Danau Beringin Indah, Danau Kemuning, Museum Budaya. Kunjungan wisata ke Kabupaten Lampung Timur, selain tempat wisata tersebut selama 2017 hingga 2018 ini hampir disetiap daerah terdapat tempat wisata baru, seperti kali aro, taman padang savanna, hutan mangrove dan lain-lain. Keberadaan tempat wisata tersebut dikelola dengan berbagai tujuan dan upaya. Upaya untuk meningkatkan pendapatan serta kesejahteraan masyarakat dan juga mengubah stigma Lampung Timur dari daerah yang dikenal "kurang aman" menjadi daerah tujuan wisata. Dengan berbagai keterbatasan yang ada tentunya membutuhkan kreativitas, inovasi, dan juga kerja keras serta kolaborasi antara satuan kerja perangkat daerah (SKPD) Lampung Timur dengan sektor swasta, tentu mempercepat perubahan citra yang hendak dilakukan.

Tujuan penelitian ini adalah Menganalisis Pengaruh Pendapatan Sektor Pariwisata Terhadap Kesejahteraan Masyarakat dan Pertumbuhan Ekonomi Lampung Timur. Hasil penelitian ini diharapkan dapat menjadi masukan bagi pembuat kebijakan (policy making) khususnya Pemerintah Daerah Kabupaten Lampung Timur dalam upaya meningkatkan perekonomian masyarakat dan kesejahteraan masyarakat.

Kata Kunci : Pendapatan Sektor Pariwisata, Kesejahteraan Masyarakat ,Pertumbuhan Ekonomi 


\section{PENDAHULUAN}

\subsection{Latarbelakang Masalah}

Lampung Timur kini terus berupaya membangkitkan pariwisata sebagai salah satu sektor unggulan. Beberapa obyek wisata yang terdapat di Kabupaten Lampung Timur, antara lain Dam Swadaya, Dam Negara Natin, Balai Benih Induk Holtikultura, Taman Nasional Way Kambas (TNWK), Pesanggrahan Way Curup, Taman Purbakala Pugung Raharjo, Pantai Kerang Mas, Desa Tradisional Wana, Danau Beringin Indah, Danau Kemuning, Museum Budaya. Kunjungan wisata ke Kabupaten Lampung Timur, selain tempat wisata tersebut selama 2017 hingga 2018 ini hampir disetiap daerah terdapat tempat wisata baru, seperti kali aro, taman padang savanna, hutan mangrove dan lain-lain. Keberadaan tempat wisata tersebut dikelola dengan berbagai tujuan dan upaya. Upaya untuk meningkatkan pendapatan serta kesejahteraan masyarakat dan juga mengubah stigma Lampung Timur dari daerah yang dikenal "kurang aman" menjadi daerah tujuan wisata. Dengan berbagai keterbatasan yang ada tentunya membutuhkan kreativitas, inovasi, dan juga kerja keras serta kolaborasi antara satuan kerja perangkat daerah (SKPD) Lampung Timur dengan sektor swasta, tentu mempercepat perubahan citra yang hendak dilakukan.

Selama 2017 hingga 2018 ini puluhan festival digelar untuk menarik minat wisatawan local maupun manca negara.Antara lain Lamtim BMX Festival, Festival Kicau Burung, Tasyakuran Laut, Pekan Seni Lamtim, Mulei Meghanai, Begawi Adat Lampung, dan Festival Kuliner Ramadan. Lalu, Petualangan Motor Cross, Gebyar Wisata Mudik, Festival LayangLayang, Festival Petik Lada, Festival Membaca, Festival Kuda Lumping, dan Festival Bersih Danau Beringin. Kemudian Festival Dayung Way Bungur, Festival Musik Kreatif, Festival Tari Melinting, Festival Seribu Pohon, Festival Sepuluh Ribu Rebana, Festival Napak Tilas Purbakala, dan Festival Wisata Way Kambas.

Menurut Purwanti dan Dewi, R. M. (2014), pengaruh jumlah kunjungan wisatawan sangat berarti untuk pengembangan industri pariwisata dan pendapatan asli daerah sehingga wisatawan domestik maupun wisatawan mancanegara tertarik untuk berkunjung. Adanya dukungan alokasi dana dari pemerintah setiap tahunnya menjadikan sektor pariwisata mengembangkan tempat wisata agar banyak dikunjungi oleh wisatawan. Banyaknya wisatawan yang berkunjung menjadikan sektor pariwisata berpotensi meningkatkan pendapatan asli daerah. Akibatnya jumlah kunjungan wisatawan memberikan kontribusi positif dalam pendapatan asli daerah.

Jumlah wisatawan di Lampung Timur terus meningkat dari tahun 2012-2016. Pada tahun 2016 jumlah wisatawan mencapai 289.568 wisatawan yang terdiri dari 652 wisatawan asing dan 288.916 wisatawan domestik. Kenaikan tahun 2016 mencapai 156,56 persen jika dibandingkan dengan tahun 2015. Jumlah wisatawan asing meningkat 24,90 persen dan wisatawan domestik meningkat 157,18 persen. Namun, pada tahun 2017 jumlah wisatawan menurun dibanding tahun sebelumnya yang hanya mencapai 188.742 wisatawan. Di balik 
penurunan tersebut, jumlah wisatawan asing meningkat signifikan dari 652 menjadi 4.049 atau 6 kali lipat di tahun 2017. Berikut adalah jumlah wisatawan di Kabupaten Lampung Timur 2012-2017.

Tabel 1. Jumlah Wisatawan Mancanegara dan Domestik di Kabupaten Lampung Timur, 2012-2017 Number of International and Domestic Visitors in Lampung Timur Regency, 2012-2017

\begin{tabular}{|c|c|c|c|}
\hline \multirow[t]{2}{*}{ Tahun } & \multicolumn{2}{|c|}{ Wisatawan } & \multirow{2}{*}{$\begin{array}{l}\text { Jumlah } \\
\text { Total }\end{array}$} \\
\hline & Mancanegara/Internasional & Domestik & \\
\hline 2012 & 390 & 57.758 & 58.148 \\
\hline 2013 & 385 & 47.429 & 47.814 \\
\hline 2014 & 462 & 63.072 & 63.534 \\
\hline 2015 & 522 & 112.342 & 112.864 \\
\hline 2016 & 652 & 288.916 & 289.568 \\
\hline 2017 & 4.049 & 184.693 & 188.742 \\
\hline
\end{tabular}

Sumber : Dinas Pariwisata Kabupaten Lampung Timur, 2018

Peningkatan jumlah wisatawan dilampung timur, memberikan dampak positif yaitu meningkatnya jumlah unit usaha seperti tempat/rumah makan dan akomodasi/hotel. Pada tahun 2016, hotel/akomodasi lainnya di Lampung Timur ada sebanyak 13 unit dengan 200 kamar dan 243 tempat tidur. Akomodasi-akomodasi ini tersebar di 8 kecamatan dari 24 kecamatan yang ada di Lampung Timur.

Selain berdampak pada meningkatnya unit usaha, jumlah wisatawan yang mengunjungi Lampung Timur terus meningkat baik wisatawan nusantara maupun wisatawan mancanegara, sehingga akan mampu meningkatkan jumlah penerimaan bagi devisa maupun PDRB.

Shakhibul Amnar, Said Muhammad, Mohd. Nur Syechalad dalam penelitiannya yang berjudul Pengaruh Pariwisata Terhadap Pertumbuhan Ekonomi Di Kota Sabang, berkesimpulan bahwa Jumlah kunjungan wisatawan mancanegara berpengaruh positif signifikan terhadap pertumbuhan ekonomi regional Kota Sabang, yaitu dilihat dari nilai pvalue adalah 0.000 dengan tingkat keyakinan 99 persen serta memiliki koefisien regresi $\beta 1=$ 0.75637, Wisawatan nusantara memiliki koefisien 0.21 dan signifikan bermakna bahwa ada pengaruh yang positif terhadap pertumbuhan ekonomi regional Kota Sabang dengan tingkat keyakinan 99 persen.

Tujuan penelitian ini adalah Menganilisis Pengaruh Pendapatan Sektor Pariwisata Terhadap Kesejahteraan Masyarakat dan Pertumbuhan Ekonomi Lampung Timur. Hasil penelitian ini diharapkan dapat menjadi masukan bagi pembuat kebijakan (policy making) khususnya Pemerintah Daerah Kabupaten Lampung Timur dalam upaya meningkatkan perekonomian masyarakat dan kesejahteraan masyarakat. 


\subsection{Rumusan Penelitian}

Berdasarkan uraian latar belakang diatas maka rumusan masalah penelitian ini adalah:

1. Apakah ada Hubungan Pendapatan Sektor Pariwisata Terhadap Kesejahteraan Masyarakat dan Pertumbuhan Ekonomi Lampung Timur?

2. Apakah ada Pengaruh Pendapatan Sektor Pariwisata Terhadap Kesejahteraan Masyarakat dan Pertumbuhan Ekonomi Lampung Timur?

\subsection{Tujuan Penelitian}

Tujuan dari penelitian ini adalah :

1. Hubungan Pendapatan Sektor Pariwisata Terhadap Kesejahteraan Masyarakat dan Pertumbuhan Ekonomi Lampung Timur?

2. Pengaruh Pendapatan Sektor Pariwisata Terhadap Kesejahteraan Masyarakat dan Pertumbuhan Ekonomi Lampung Timur?

\section{TINJAUAN PUSTAKA}

\subsection{Pendapatan Sektor Wisata terhadap Pertumbuhan Ekonomi}

Pertumbuhan ekonomi adalah proses kenaikan output perkapita yang terus menerus dalam jangka panjang. (Sadono Sukirno, 2000:33),

Menurut Prof. Simon Kuznets, pertumbuhan ekonomi adalah kenaikan jangka panjang dalam kemampuan suatu negara untuk menyediakan semakin banyak barangbarang ekonomi kepada penduduknya. Kemampuan ini tumbuh sesuai dengan kemajuan teknologi, dan penyesuaian kelembagaan, dan ideologis yang diperlukannya.

Dalam Peraturan Presiden Republik Indonesia Nomor 5 Tahun 2010 Tentang Rencana Jangka Panjang Menengah Nasional (RPJMN) 2010-2014 menyatakan bahwa pariwisata mempunyai peranan penting dalam mendorong kegiatan ekonomi, meningkatkan citra Indonesia, meningkatkan kesejahteraan masyarakat, dan memberikan perluasan kesempatan kerja. Peran tersebut, antara lain ditunjukan oleh kontribusi kepariwisataan dalam penerimaan devisa Negara yang dihasilkan oleh kunjungan wisatawan mancanegara, nilai tambah PDRB, dan penyerapan tenaga kerja. Hal tersebut sejalan dengan tujuan pengembangan pariwisata sesuai UndangUndang Republik Indonesia No 10 Tahun 2009.

Hasil penelitian dilakukan oleh Handayani di Jawa Tengah (2012) menemukan bahwa jumlah obyek wisata berpengaruh signifikan terhadap pertumbuhan ekonomi daerah Jawa Tengah. Hal ini disebabkan oleh meningkatnya retribusi obyek pajak berdasarkan peningkatan jumlah obyek wisata yang terdapat di Jawa Tengah. Salah satu komponen Pendapatan Asli Daerah yang berpotensi tinggi adalah pajak hotel. Semakin besar pendapatan dari pajak hotel maka akan semakin besar pendapatan asli daerah yang diterima. 
Penelitian yang sama dilakukan oleh Bojanic dan Lo (2016) menemukan bahwa pariwisata sangat berpengaruh pada pertumbuhan ekonomi di sebagian besar negaranegara terutama negara yang terdiri dari pulau-pulau. Negara kepulauan memiliki lebih banyak obyek wisata sehingga pendapatan dari pajak dan retribusi yang diperoleh melalui obyek wisata tersebut mampu mendongkrak pertumbuhan ekonomi daerah

Dari penjelasan-penjelasan diatas salah satu manfaat sektor parawisata dan pembangunan ekonomi adalah kenyataan bahwa kawasan wisata bersemangat menyediakan lapangan kerja bagi warga daerah itu. Pariwisata membutuhkan banyak jasa dalam rangka untuk mempertahankan industri.misalnya, industri perhotelan menciptakan lapangan pekerjaan bagi orang-orang dibisnis seperti hotel dan restoran. Pekerjaan adalah faktor makro ekonomi yang memberikan kontribusi terhadap pertumbuhan ekonomi dengan menyediakan pekerja dengan pendapatan disposable dan akibatnya menyebabkan peningkatan Produk Domestik Bruto (PDB) Daerah.

\subsection{Pendapatan Sektor Wisata terhadap Kesejahteraan Masyarakat}

Santosa (2013) mengatakan, bahwa peningakatan pendapatan asli daerah yang dianggap sebagai modal secara akumulasi akan lebih banyak menimbulkan efek positif dan akan mempercepat pertumbuhan ekonomi. Selanjutnya peningkatan pendapatan asli daerah pada akhirnya akan dapat meningkatkan kesejahteraan masayarakat. Sehingga pemerintah daerah memiliki kewenangan untuk terus berupaya menggali sumber-sumber keuangan sendiri, mengelola, dan memanfaatkannya untuk membiayai penyelenggaraan pemerintahaan daerah Koswara (2000).

Indikator kesejahteraan masyarakat yang disusun oleh UNDP dikenal dengan Human Develovment Index (HDI), merupakan perangkat yang sangat bermanfaat untuk mengukur tingkat kesejahteraan antar negara maupun antar daerah (Todaro, 2009:57). Indikator HDI jauh melebihi pertumbuhan konvensional. Pertumbuhan ekonomi penting untuk mempertahankan kesejahteraan rakyatnya, namun pertumbuhan bukan akhir dari pembangunan manusia. Pertumbuhan hanyalah salah satu alat, yang lebih penting adalah bagaimana pertumbuhan ekonomi di gunakan untuk memperbaiki kapabilitas manusianya dan bagaimana rakyat menggunakan kapabilitasnya tersebut. Tingkat pembangunan manusia yang tinggi sangat menentukan kemampuan penduduk dalam mengelola sumber-sumber pertumbuhan ekonomi, baik kaitanya dengan teknologi maupun terhadap kelembagaan untuk mencapai suatu pertumbuhan ekonomi (Brata, 2005).

penelitian ini didukung oleh

Penelitian Waskito (2013), berdasarkan hasil analisis dalam peneletiannya dijelaskan bahwa variabel tingkat hunian hotel berpengaruh terhadap meningkatnya 
kesejahteraan masyarakat. Ini berarti tingkat hunian hotel dapat mensejahterakan masyarakatnya dengan menyerap tenaga kerja dari masyarakat di daerah tujuan wisata untuk ikut dalam membangun pariwisata, sehingga dapat meningkatkan kesejahteraan masyarakat dari sektor pariwisata.

\subsection{Hipotesis}

Berdasarkan kajian teoritis dan hasil-hasil penelitian terdahulu, maka hipotesis yang dikembangkan pada penelitian ini adalah:

1. Pendapatan Sektor Pariwisata berpengaruh positif Terhadap Kesejahteraan Masyarakat dan Pertumbuhan Ekonomi Lampung Timur .

2. Pendapatan Sektor Pariwisata berpengaruh positif Terhadap Kesejahteraan Masyarakat melalui Pertumbuhan Ekonomi Lampung Timur.

\subsection{Kerangka Konsep Penelitian}

Gambar 1. Skematik Model Penelitian

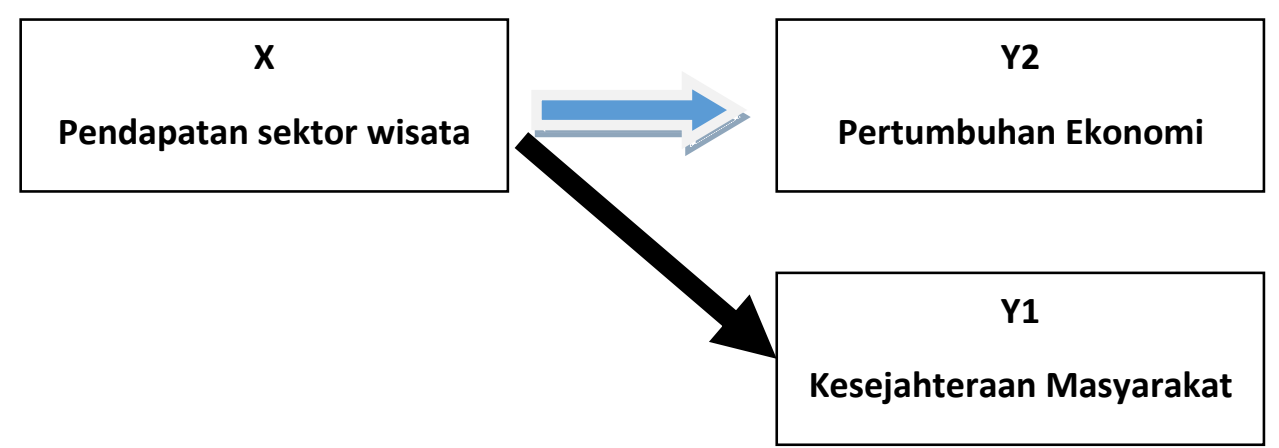

\section{METODE PENELITIAN}

\subsection{Jenis Penelitian}

Jenis penelitian yang digunakan adalah Deskriptif kuantitatif, yaitu metode penelitian adalah pendekatan ilmiah terhadap keputusan ekonomi.

\subsection{Lokasi dan Waktu Penelitian}

Untuk keperluan penulisan ini, penulis memilih objek di Lampung Timur sebagai daerah penelitian. Waktu penelitian dilakasanakan selama 5 (lima) bulan yaitu dari Mei sampai September.

\subsection{Definisi Operasional:}

\section{Variabel Independen ( XI )}

Dalam penelitian ini yang menjadi variabel XI Yaitu pendapatan sektor wisata. 
Pendapatan dari sektor wisata yang termasuk dalam penerimaan daerah Tahun 2011-2017 diantaranya adalah retribusi tempat rekrasi dan olahraga, pendapatan lain-lain yang sah diukur dengan satuan rupiah

\section{Variabel Dependent (Y)}

Y1 = Kesejahteraan Masyarakat dalam penelitian ini mnggunakan Indeks Pembangunan Manusia (IPM) atau Human Development Index (HDI) sebagai indikator kesejahteraan Masyarakat

Y2 = Pertumbuhan Ekonomi dalam penelitian ini adalah PDRB (Pendapatan Daerah Regional Bruto) atas dasar harga konstan.

\subsection{Teknik Pengumpulan Data}

Pada penelitian pustaka/dokumentasi dipakai untuk mengetahui pengaruh sektor pariwisata terhadap Kesejahteraan dan Pertumbuhan Ekonomi Lampung Timur.

\subsection{Teknik Analisis Data}

Dalam melakukan pengolaan data, penulis menggunakan alat analisa data sebagai berikut:

\section{Analisis Kuantitatif}

Menekankan pada pengujian teori-teori melalui pengukuran variable variabel penelitian dengan angka dan melakukan analisis data dengan prosedur statistik (Indriantoro dan Supomo,1999 : 97).

2. Analisis Jalur

Ghozali (2013:249), menyatakan bahwa:

“Analisis jalur merupakan perluasan dari analisis linear berganda, atau analisis jalur adalah penggunaan analisis regresi untuk menaksir hubungan kausalitas antar variabel (model kausal) yang telah ditetapkan sebelumnya berdasarkan teori”.

Analisis jalur sendiri tidak menentukan hubungan sebab-akibat dan juga tidak dapat digunakan sebagai subtitusi bagi peneliti untuk melihat hubungan kausalitas antar variabel. Hubungan kausalitas antar variabel telah dibentuk dengan model berdasarkan landasan teoritis. Apa yang dilakukan oleh analisis jalur adalah menentukan pola hubungan antara tiga atau lebih variabel dan tidak dapat digunakan untuk mengkonfirmasi atau menolak hipotesis kausalitas imajiner. 


\section{HASIL DAN PEMBAHASAN}

\subsection{Kesejahteraan Masyarakat}

Model pengukuran variabel kesejahteraan masyarakat mengacu pada teori yang dikemukakan Moris (1979) dan UNDP (1990) dalam Todaro (2000), yang menyatakan bahwa kesejahteraan masyarakat merupakan indeks komposit dari tiga indikator, yaitu indikator kesehatan (angka harapan hidup), indikator pendidikan (angka harapan lama sekolah dan rata-rata lama sekolah), dan indikator pengeluaran per kapita. Selanjutnya Indeks Pembangunan Manusia (IPM) Kabupaten Lampung Timur ditampilkan pada Tabel 2.

Tabel 2. Indeks Pembangunan Manusia (IPM) Kabupaten Lampung Timur Tahun 2010-2017

\begin{tabular}{|c|c|c|c|c|c|}
\hline Tahun & $\begin{array}{c}\text { Angka } \\
\text { harapan hidup } \\
\text { (tahun) }\end{array}$ & $\begin{array}{c}\text { Angka } \\
\text { harapan lama } \\
\text { sekolah } \\
\text { (tahun) }\end{array}$ & $\begin{array}{c}\text { Rata-rata lama } \\
\text { sekolah } \\
\text { (tahun) }\end{array}$ & $\begin{array}{c}\text { Pengeluaran per } \\
\text { kapita disesuaikan } \\
\text { (ribu rupiah) }\end{array}$ & IPM \\
\hline 2010 & 68,78 & 10,95 & 6,76 & $8.086,46$ & 63,23 \\
\hline 2011 & 68,86 & 11,30 & 6,87 & $8.327,9$ & 64,10 \\
\hline 2012 & 68,94 & 11,78 & 7,01 & $8.541,9$ & 65,10 \\
\hline 2013 & 69,01 & 12,26 & 7,15 & $8.755,91$ & 66,07 \\
\hline 2014 & 69,33 & 12,38 & 7,16 & $8.814,14$ & 66,42 \\
\hline 2015 & 69,73 & 12,40 & 7,20 & $9.194,29$ & 67,10 \\
\hline 2016 & 69,92 & 12,41 & 7,55 & 9.416 & 67,88 \\
\hline 2017 & 70,11 & 12,44 & 7,56 & 9.453 & 68,05 \\
\hline
\end{tabular}

Sumber : Badan Pusat Statistik Lampung Timur, 2018

Berdasarkan Tabel 2 diatas, nilai IPM Kabupaten Lampung Timur mengalami kenaikan setiap tahunnya, pada tahun 2010 nilai IPM sebesar 63,23 poin sedangkan tahun 2017 mencapai angka 68,05 poin. Hal ini berarti nilai IPM Kabupaten Lampung Timur dalam delapan tahun terakhir selalu mengalami peningkatan. Peningkatan tersebut dicapai akibat adanya kenaikan di semua nilai indeks/indikator, yaitu indikator kesehatan, indikator pendidikan dan indikator pengeluaran.

\subsection{Pertumbuhan Ekonomi}

Pertumbuhan ekonomi terjadi kenaikan output per kapita. Pertumbuhan ekonomi menggambarkan kenaikan taraf hidup diukur dengan output riil per orang. Salah satu untuk melihat kemajuan perekonomian adalah dengan mencermati nilai Produk Domestik Regional Bruto (PDRB). PDRB merupakan nilai dari seluruh barang dan jasa yang diproduksi dalam jangka waktu tertentu biasanya dalam waktu satu tahun disuatu wilayah tertentu tanpa membedakan kepemilikan faktor-faktor produksi yang digunakan dalam proses produksi tersebut. 
Pembangunan dunia pariwisata dan budaya tidak dapat berjalan sendiri tanpa dukungan dari semua pihak baik pemerintah, pelaku usaha (swasta), dan seluruh lapisan masyarakat. Berbagai upaya yang telah dilakukan oleh Pemerintah Kabupaten Lampung Timur dalam mengembangkan sektor pariwisata dan kebudayaan yang nantinya akan meningkatkan Pendapatan Asli Daerah yang tercermin dalam PDRB, yang merupakan alat untuk mengukur pertumbuhan ekonomi. Berikut adalah data Pertumbuhan Ekonomi PDRB Kabupaten Lampung Timur atas dasar harga konstan 2010.

Tabel 3. Pertumbuhan Ekonomi Kabupaten Lampung Timur Tahun 2011-2017

\begin{tabular}{|c|c|c|}
\hline Tahun & $\begin{array}{c}\text { PDRB Atas Dasar Harga Konstan 2010 } \\
\text { (miliar rupiah) }\end{array}$ & Pertumbuhan (\%) \\
\hline 2010 & $19.496,11$ & 5,57 \\
\hline 2011 & $20.582,08$ & 4,24 \\
\hline 2012 & $21.455,32$ & 8,96 \\
\hline 2013 & $23.378,06$ & 2,87 \\
\hline 2014 & $24.049,30$ & 4,58 \\
\hline 2015 & $25.151,47$ & 4,23 \\
\hline 2016 & $26.214,19$ & 4,64 \\
\hline 2017 & $27.429,66$ & - \\
\hline
\end{tabular}

Sumber : BPS Lampung Timur dalam Angka, 2018

Berdasarkan Tabel 3 diatas, dalam kurun waktu tahun 2011-2017, kondisi pertumbuhan ekonomi di Kabupaten Lampung Timur berfluktuasi dari kisaran 5,57 \% sampai dengan 4,64\%. Pertumbuhan ekonomi tertinggi terjadi pada tahun 2013 sebesar 8,96\%, sedangkan pertumbuhan ekonomi terendah terjadi pada tahun 2014 sebesar 2,87\%. Laju pertumbuhan ekonomi Lampung Timur pada tahun 2017 sebesar 4,64\%, naik dibandingkan dengan tahun 2016 yang hanya sebesar 4,23\%.

\subsection{Sektor Pariwisata}

Potensi wisata di Kabupaten Lampung Timur cukup beragam, wisata budaya, wisata agro, wisata bahari, wisata cagar budaya dan wisata lainnya. Lampung Timur setidaknya memiliki 20 tempat wisata yang menjadi daya tarik wisatawan. Taman Nasional Way Kambas adalah salah satu tempat wisata nasional yang ada di Lampung Timur. Sektor pariwisata merupakan potensi yang apabila dieksplorasi dengan baik akan mendatangkan Pendapatan Asli Daerah yang dapat ditarik masih terbatas pada tempat rekreasi, hotel dan restaurant, rumah makan, penginapan, kios/cafe dan karoke. Sektor pariwisata diyakini mampu menggerakan ekonomi rakyat. Karena dianggap sektor yang paling siap dari segi fasilitas, sarana dan prasarana dibandingkan dengan sektor usaha lainya. Dengan datangnya wisatawan ke Kabupaten Lampung Timur maka membuka peluang bagi masyarakat untuk menjadi 
pengusaha atau pengelola hotel, restoran, jasa angkutan dan pengelolaan obyek daya tarik wisata.

Undang-undang Nomor 10 tahun 2009, menyebutkan pariwisata adalah segala sesuatu yang berhubungan dengan wisata, termasuk pengusahaan obyek dan daya tarik wisata serta usaha-usaha yang berhubungan dengan penyelenggaraan pariwisata, dengan demikian pariwisata meliputi: (1) semua kegiatan yang berhubungan dengan perjalanan wisata, (2) Pengusahaan obyek dan daya tarik wisata, (3) Pengusahaan jasa dan sarana pariwisata.

Untuk mengukur pengaruh pariwisata terhadap perekonomian suatu wilayah/daerah dapat dilakukan melalui pendekatan pengeluaran wisatawan (tourist expenditure) dan pendekatan permintaan wisatawan (tourist demand) terhadap barang dan jasa. Pengeluaran wisatawan adalah pengeluaran yang dilakukan wisatawan selama melakukan perjalanan wisata. Pengeluaran wisatawan dapat berupa akomodasi, konsumsi makanan, angkutan wisata, atau jasa-jasa lainnya. Permintaan langsung wisatawan dapat digunakan untuk melihat kontribusi wisatawan terhadap PDRB (BPS, 2001).

Berdasarkan hal tersebut, pendapatan sektor pariwisata Kabupaten Lampung Timur dihitung melalui PDRB Kabupaten Lampung Timur atas dasar harga konstan menurut lapangan usaha penyediaan akomodasi dan makan minum dan jasa lainnya. Pendapatan sektor pariwisata Kabupaten Lampung Timur terus meningkat dari kurun waktu tahun 2010-2017. Pada tahun 2010 pendapatan sektor pariwisata sebesar 321,13 miliar rupiah dengan pertumbuhan 5,36\% dan tahun 2017 pendapatan sektor pariwisata sebesar 488,64 miliar rupiah dengan pertumbuhan $8,50 \%$. Pendapatan sektor pariwisata Kabupaten Lampung Timur tahun 2010-2017 disajikan dalam Tabel 4 berikut.

Tabel 4. Pendapatan Sektor Pariwisata Kabupaten Lampung Timur Tahun 2010-2017

\begin{tabular}{|c|c|c|}
\hline Tahun & $\begin{array}{c}\text { Pendapatan Sektor Wisata } \\
\text { (miliar rupiah) }\end{array}$ & $\begin{array}{c}\text { Pertumbuhan } \\
(\%)\end{array}$ \\
\hline 2010 & 321,13 & 5,36 \\
\hline 2011 & 338,22 & 5,46 \\
\hline 2012 & 356,71 & 5,45 \\
\hline 2013 & 376,15 & 5,86 \\
\hline 2014 & 398,25 & 8,69 \\
\hline 2015 & 432,88 & 4,04 \\
\hline 2016 & 450,35 & 8,50 \\
\hline 2017 & 488,64 & - \\
\hline
\end{tabular}

Sumber : BPS Lampung Timur dalam Angka, 2018 


\subsection{Hasil Penelitian}

Analisis Infrensial dalam penelitian ini menggunakan analisis jalur (path analysis). Analisis jalur adalah penggunaan analisis regresi untuk mengetahui tingkat pengaruh pada suatu hubungan kausal antar variabel model kasual) yang telah ditetapkan sebelumnya, berikut rekapitulasi hasil analisis jalur persamaan regresi.

\subsubsection{Analisis Jalur Persamaan Regresi}

\subsubsection{Pengaruh Pendapatan Sektor Pariwisata terhadap Pertumbuhan Ekonomi}

Analisis jalur persamaan regresi model pertama, pendapatan sektor pariwisata (X) terhadap kesejahteraan masyarakat (Y2). Untuk menguji ada tidaknya pengaruh variabel independent terhadap dependent maka dilakukan pengujian model regresi dengan bantuan program komputer statistik SPSS 22.

Dari hasil uji SPSS 22 diperoleh rekapitulasi output model hasil persamaan regresi sebagai berikut:

Tabel 5. Rekapitulasi Analisis antara X terhadap Y2

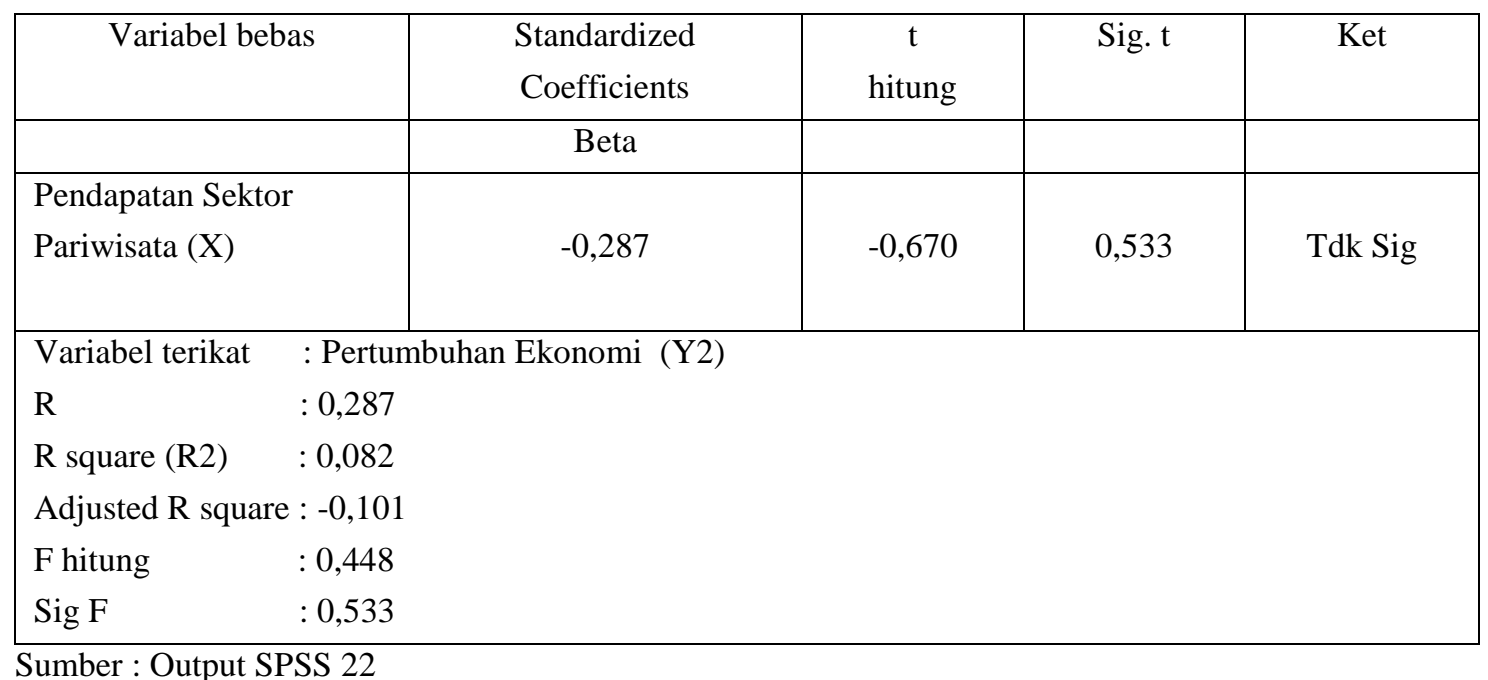

Berdasarkan Tabel 5, hasil perhitungan secara parsial variabel pendapatan sektor pariwisata $(\mathrm{X})$ mempunyai pengaruh yang negatif dan tidak signifikan terhadap pertumbuhan ekonomi (Y2) pada tingkat kesalahan 0,05 ( $\alpha=5 \%$ ), apabila variabel lain diasumsikan konstan. Hal ini dibuktikan dengan besarnya koefisien path sebesar $-0,287$ dengan nilai Sig. $t$ sebesar 0,533 (0,533 > 0,05), maka secara parsial pendapatan sektor pariwisata $(\mathrm{X})$ tidak signifikan mempengaruhi pertumbuhan ekonomi (Y2).

Besarnya sumbangan (kontribusi) variabel pendapatan sektor pariwisata terhadap pertumbuhan ekonomi dapat dilihat dari nilai $\mathrm{R}$ square $(\mathrm{R})$ yaitu sebesar 0,082 . Artinya bahwa $8,2 \%$ variabel pertumbuhan ekonomi dipengaruhi oleh variabel 
bebasnya yaitu pendapatan sektor pariwisata. Sedangkan sisanya 91,8\% dijelaskan atau dipengaruhi oleh faktor-faktor lain yang tidak diteliti atau diluar model.

\subsubsection{Pengaruh Pendapatan Sektor Pariwisata terhadap Kesejahteraan Masyarakat dan Pertumbuhan Ekonomi}

Analisis jalur persamaan regresi model kedua, pendapatan sektor pariwisata $(X)$ dan pertumbuhan ekonomi (Y2) terhadap kesejahteraan masyarakat (Y1). Untuk menguji ada tidaknya pengaruh variabel independent terhadap dependent maka dilakukan pengujian model regresi dengan bantuan program komputer statistik SPSS 22.

Dari hasil uji SPSS 22 diperoleh rekapitulasi output model hasil persamaan regresi sebagai berikut:

Tabel 6. Rekapitulasi Analisis antara X dan Y2 terhadap Y1

\begin{tabular}{|c|c|c|c|c|}
\hline \multirow[t]{2}{*}{ Variabel bebas } & $\begin{array}{c}\text { Standardized } \\
\text { Coefficients }\end{array}$ & $\begin{array}{c}\mathrm{t} \\
\text { hitung }\end{array}$ & Sig. $\mathrm{t}$ & Ket \\
\hline & Beta & & & \\
\hline $\begin{array}{l}\text { Pendapatan Sektor } \\
\text { Pariwisata }(\mathrm{X})\end{array}$ & 0,980 & 7,189 & 0,002 & Sig \\
\hline $\begin{array}{l}\text { Pertumbuhan Ekonomi } \\
\text { (Y2) }\end{array}$ & 0,580 & 0,427 & 0,691 & Tdk Sig \\
\hline \multicolumn{5}{|c|}{ Variabel terikat $\quad$ : Kesejahteraan Masyarakat (Y1) } \\
\hline \multicolumn{5}{|c|}{$\mathrm{R} \quad: 0,965$} \\
\hline \multicolumn{5}{|c|}{ R square (R2) : : 0,932 } \\
\hline \multicolumn{5}{|c|}{ Adjusted R square : 0,898} \\
\hline \multicolumn{5}{|c|}{ F hitung $\quad: 27,301$} \\
\hline Sig F & & & & \\
\hline
\end{tabular}

Sumber : Output SPSS 22

Berdasarkan Tabel 6, dari hasil uji koefisien path nilai Sig F (uji F) terlihat bahwa secara simultan variabel pendapatan sektor pariwisata dan pertumbuhan ekonomi memiliki pengaruh yang signifikan terhadap variabel kesejahteraan ekonomi. Hal ini ditunjuukan dari nilai Sig F sebesar 0,005, karena lebih kecil dari $0,05(0,005<0,05)$ maka hipotesis pertama yang diajukan yaitu "Pendapatan Sektor Pariwisata berpengaruh positif terhadap Kesejahteraan Masyarakat dan Pertumbuhan Ekonomi Lampung Timur, dapat diterima

Pengaruh variabel pendapatan sektor pariwisata $(\mathrm{X})$ terhadap kesejahteraan masyarakat (Y1). Dari hasil perhitungan secara parsial pendapatan sektor pariwisata (X) mempunyai pengaruh yang positif dan signifikan terhadap kesejahteraan masyarakat (Y1) pada tingkat kesalahan $0,05(\alpha=5 \%)$ apabila variabel lain diasumsikan konstan. Hal ini dapat dibuktikan dengan besarnya koefisien path sebesar 0,980 dengan nilai Sig t sebesar 0,002 $(0,002<0,005)$, maka secara parsial 
variabel pendapatan sektor pariwisata $(\mathrm{X})$ berpengaruh signifikan terhadap kesejahteraan masyarakat (Y1).

Pengaruh variabel pertumbuhan ekonomi terhadap kesejahteraan masyarakat. Dari hasil perhitungan secara parsial pertumbuhan ekonomi (Y2) mempunyai pengaruh yang positif dan tidak signifikan terhadap kesejahteraan masyarakat (Y1) pada tingkat kesalahan $0,05(\alpha=5 \%)$ apabila variabel lain diasumsikan konstan. Hal ini dapat dibuktikan dengan besarnya koefisien path sebesar 0,580 dengan nilai Sig t sebesar 0,691 (0,691 > 0,005), maka secara parsial variabel pertumbuhan ekonomi (Y2) berpengaruh tidak signifikan terhadap kesejahteraan masyarakat (Y1).

Nilai korelasi (R) sebesar 0,965 (96,5\%), artinya tingkat hubungan antara pendapatan sektor pariwisata terhadap kesejahteraan masyarakat dan pertumbuhan ekonomi sangat kuat dan positif. Besarnya sumbangan (kontribusi) variabel pendapatan sektor pariwisata dan pertumbuhan ekonomi terhadap kesejahteraan masyarakat dapat dilihat dari nilai $\mathrm{R}$ square $(\mathrm{R})$ yaitu sebesar 0,932. Artinya bahwa 93,2\% variabel kesejahteraan masyarakat dipengaruhi oleh variabel bebasnya yaitu pendapatan sektor pariwisata dan pertumbuhan ekonomi. Sedangkan sisanya 6,8\% dijelaskan atau dipengaruhi oleh faktor-faktor lain yang tidak diteliti atau diluar model.

Berdasarkan hasil persamaan regresi dengan analisis jalur, dibuat ringkasan koefisien jalur seperti yang disajikan pada gambar 2 berikut:

$-0,287$ (Sig $\mathrm{t}=\mathbf{0 , 5 3 3 )}$

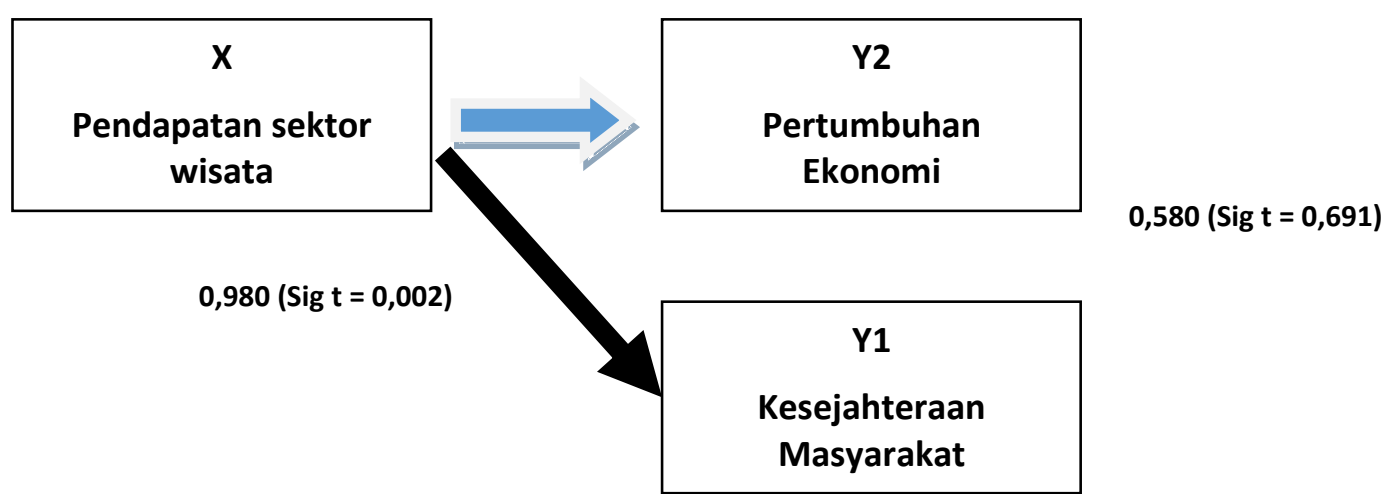

Gambar 2. Model analisis Jalur Keseluruhan 


\section{KESIMPULAN DAN SARAN}

\subsection{Kesimpulan}

Berdasarkan analisis yang telah dilakukan dalam penelitian ini, maka dapat diambil kesimpulan sebagai berikut:

1. Hubungan antara pendapatan sektor pariwisata terhadap kesejahteraan masyarakat dan pertumbuhan ekonomi sangat kuat dan positif. Hal ini dibuktikan dengan nilai korelasi (R) sebesar 0,965 (96,5\%).

2. Pendapatan sektor pariwisata berpengaruh positif dan signifikan terhadap kesejahteraan masyarakat dan pertumbuhan ekonomi. hal ini dibuktikan dengan dari nilai $\mathrm{R}$ square $(\mathrm{R})$ yaitu sebesar 0,932. Artinya bahwa 93,2\% variabel kesejahteraan masyarakat dipengaruhi oleh pendapatan sektor pariwisata dan pertumbuhan ekonomi, sedangkan sisanya $6,8 \%$ dijelaskan atau dipengaruhi oleh faktor-faktor lain yang tidak diteliti atau diluar model.

\subsection{Saran}

Berdasarkan kesimpulan diatas, maka saran yang dapat diberikan oleh peneliti adalah sebagai berikut:

1. Bagi Pemerintah Kabupaten Lampung Timur diharapkan dalam mengembangkan sektor pariwisata dapat melakukan dengan menggalakkan promosi kepariwisataan secara kolektif, memaksimalkan penataan yang baik di seluruh obyek wisata, serta memaksimalkan koordinasi pemerintah dengan pihak-pihak yang berhubungan dengan kegitan pariwisata agar wisatawan mengetahui tentang pariwisata di Lampung Timur dan bertransaksi sehingga dapat meningkatkan pendapatan sektor pariwisata.

2. Bagi Pemerintah Kabupaten Lampung Timur diharapkan sebaiknya menambah sarana dan prasarana di oyek wisata agar masyarakat bisa membuka kegiatan usaha di objek wisata dan memberikan kenyamanan dan keamanan bagi wisatawan agar dapat menarik minat wisatawan untuk berkunjung.

3. Bagi masyarakat seharusnya dapat memperluas kesempatan berusaha ketika objek wisata dikunjungi wisatawan agar dapat memperluas kesempatan bekerja dan menghasilkan pendapatan yang lebih untuk meningkatkan kesejahteraan.

\section{DAFTAR PUSTAKA}

Adi, Suyatmin Waskito dan Rahmawati, Aryani Intan Endah. 2015. "Analisis Rasio Keuangan Terhadap Kondisi Financial Distress Pada Perusahaan Manufaktur Yang Terdaftar Di Bursa Efek Indonesia Tahun 2008-2013”, Jurnal Ekonomi dan Bisnis, ISSN: 2460-0784. 
Anang Santoso, dkk. 2013. Materi dan Pembelajaran Bahasa Indonesia, (Banten : Universitas Terbuka)

Bojanic, D.C \& Lo, M. (2016).A comparison of the moderating effect of tourism reliance on the economic development for islands and other countries.Tourism Management, Vol.53, Hal.207-214.

Brata, Aloysius Gunadi. 2004. Komposisi Penerimaan Sektor Publik Dan Pertumbuhan Ekonomi Regional. Lembaga Penelitian Universitas Atma Jaya Yogyakarta.

Dinas Pariwisata Kabupaten Lampung Timur 2017

Handayani, 2012, Analisis kontribusi sector pariwisata terhadap pendapatan asli daerah di kabupaten ngawi tahun 2003-2010

Kuznets, Simon. 1955. "ECONOMIC GROWTH AND INCOME INEQUALITY*”. The American Economic Review, VOLUME XLV MARCH, 1955 NUMBER ONE

Purwanti, N.D., dan Dewi, R.M. 2014. Pengaruh Jumlah Kunjungan Wisatawan terhadap Pendapatan Asli Daerah Kabupaten Mojokerto tahun 2006-2013, Jurnal ilmiah Program Studi Pendidikan Ekonomi.Fakultas Ekonomi: Universitas Negeri Surabaya.

Peraturan Presiden Republik Indonesia Nomor 5 Tahun 2010 Tentang Rencana Jangka Panjang Menengah Nasional (RPJMN) 2010-2014

Sukirno, Sadono. 2000. Makroekonomi Modern. Jakarta:PT Raja Drafindo Persada.

Shakhibul Amnar, Said Muhammad, Mohd. Nur Syechalad Pengaruh Pariwisata Terhadap Pertumbuhan Ekonomi Di Kota Sabang, JURNAL EKONOMI DAN KEBIJAKAN PUBLIKINDONESIA Volume 4Nomor1, Mei 2017

Todaro, Michael P.dan Stephen C. Smith. 2006.Pembangunan Ekonomi (edisi kesembilan, jilid I) Jakarta : Erlangga.

Undang-Undang Republik Indonesia No 10 Tahun 2009 